\title{
PAPER
}

\section{Lipoprotein(a), apolipoprotein E genotype, and risk of Alzheimer's disease}

\author{
V Solfrizzi, F Panza, A D’Introno, A M Colacicco, C Capurso, A M Basile, A Capurso
}

\begin{tabular}{|c|c|}
\hline $\begin{array}{l}\text { ee end of article for } \\
\text { uthors' affiliations } \\
\ldots \ldots \ldots \ldots \ldots \ldots\end{array}$ & J Neurol Neurosurg Psychiatry 2002;72:732-736 \\
\hline $\begin{array}{l}\text { Correspondence to: } \\
\text { Dr A Capurso, } \\
\text { Department of Geriatrics, } \\
\text { Centre for Aging Brain, } \\
\text { Memory Unit, University of } \\
\text { Bari, Policlinico, Piazza } \\
\text { Giulio Cesare 11, } 70124 \\
\text { Bari, Italy; } \\
\text { a.capurso@geriatria.uniba.it } \\
\text { or Dr Vincenzo Solfrizzi; } \\
\text { geriat.dot@geriatria.uniba.it } \\
\text { Received } \\
19 \text { October } 2001 \\
\text { In revised form } \\
1 \text { February } 2002 \\
\text { Accepted } \\
13 \text { February } 2002\end{array}$ & $\begin{array}{l}\text { Objectives: To explore the possible role of serum lipoprotein(a) (Lp(a)), apolipoprotein E } \\
\text { polymorphism, and total cholesterol (TC) serum concentrations in Alzheimer's disease (AD). } \\
\text { Methods: Lp(a) serum concentrations, apolipoprotein E genotypes, and TC serum concentrations were } \\
\text { determined in } 61 \text { patients with a diagnosis of probable AD and in } 63 \text { healthy unrelated age matched } \\
\text { controls. Genomic DNA was obtained and amplified by polymerase chain reaction and apolipopro- } \\
\text { tein E genotypes were defined following a previously described procedure. } \\
\text { Results: Lp(a) serum concentrations were significantly associated in a non-linear relation with an } \\
\text { increased risk for AD, independently of apolipoprotein E genotypes and sex and dependent on age } \\
\text { (truth association) and TC serum concentrations (spurious association). The effect of age adjusted for } \\
\text { TC on the odds of having AD increased non-linearly with increasing Lp(a) serum concentrations, with a } \\
\text { plateau between } 70 \text { and } 355 \text { mg/l (odds ratio } 11.33 \text { ). For Lp(a) serum concentrations } \geqslant 360 \mathrm{mg} / \mathrm{l} \text {, } \\
\text { the effect of age ( } \geqslant 72 \text { years) was associated with a reduction in odds of having AD (odds ratio } 0.15) \text {. } \\
\text { Conclusion: It is suggested that increased Lp(a) serum concentrations, by increasing the risk for cer- } \\
\text { ebrovascular disease, may have a role in determining clinical AD. }\end{array}$ \\
\hline
\end{tabular}

nheritance of the $\epsilon 4$ allele of the apolipoprotein $\mathrm{E}$ gene increases the risk for sporadic and familial late onset Alzheimer's disease (AD) in comparison with the other two common alleles, $\epsilon 2$ and $\epsilon 3$. ${ }^{1}$ The association of apolipoprotein $\mathrm{E}$ $\epsilon 4$ allele with increased serum total cholesterol (TC), low density lipoprotein (LDL) cholesterol, and apolipoprotein B and with an increased risk of $\mathrm{AD}$ raises the question about the relation between serum lipoprotein concentrations, apolipoprotein E polymorphism, and AD risk. Several studies have found increased serum concentrations of TC, LDL cholesterol, and apolipoprotein $\mathrm{B}$ in patients with $\mathrm{AD} .{ }^{23}$ Epidemiological studies have further shown that the onset of AD occurs earlier in apolipoprotein $\mathrm{E} \epsilon 4$ carriers with high serum cholesterol. ${ }^{4}$ A recent study reported that subjects with a history of high TC serum concentrations during middle age or early old age have an increased risk of developing $\mathrm{AD}$ in old age, after controlling for age and the presence of apolipoprotein $\mathrm{E} \epsilon 4$ allele. ${ }^{5}$ On the contrary, the Kuopio study reported a cross sectional association between AD and lower cholesterol. ${ }^{6}$ Lipoprotein(a) (Lp(a)), an LDL-like particle with apolipoprotein(a) bound to apolipoprotein B100 through a disulphide bond, is believed to have atherogenic and thrombotic properties. ${ }^{7}$ Increased plasma concentration of $\mathrm{Lp}(\mathrm{a})$ has been associated with cerebrovascular disease. ${ }^{8}$ Furthermore, a recent study found that serum concentrations of Lp(a) were significantly higher in patients with vascular dementia, as well as in patients with cerebrovascular disease, than in healthy people.. These abnormally high serum concentrations of $\operatorname{Lp}(\mathrm{a})$ seemed to be caused by a specific increase in low molecular weight apolipoprotein(a) isoforms in Lp(a). Several lines of evidence linking clinical expression of $\mathrm{AD}$ with cerebral infarct suggest that $\operatorname{Lp}(\mathrm{a})$ is a possible risk factor in the development of AD. ${ }^{10}$ In a recent report of Mooser et al, ${ }^{11} \mathrm{Lp}(\mathrm{a})$ was an additional risk factor for late onset $\mathrm{AD}$ in $\epsilon 4$ carriers, while this lipoprotein may protect against the disease in non-carriers older than 80 years. Finally, we found that increased Lp(a) serum concentrations were significantly associated with an increased risk for age related cognitive decline, dependent on high serum concentrations of apolipoprotein A I, the major apolipoprotein in the central nervous system together with apolipoprotein E. ${ }^{12}$ We suggest that increased serum concentrations of $\operatorname{Lp}(\mathrm{a})$, by increasing the risk for subclinical atherosclerosis and silent cerebrovascular disease, may increase the risk for decline in cognitive functioning in the elderly. The aim of the present study was to evaluate the relations between sporadic $\mathrm{AD}$ and $\mathrm{Lp}(\mathrm{a})$, TC serum concentrations, and apolipoprotein E polymorphism.

\section{METHODS}

A total sample of 124 subjects from Apulia (Southern Italy) was studied. Sixty one patients with AD (18 men and 43 women, mean (SD) age 71.36 (9.55) years) and 63 unrelated caregivers, spouses, friends, neighbours, or volunteers $(30$ men and 33 women, mean (SD) age 67.67 (10.66) years) who presented themselves to the Centre for Aging Brain, Memory Unit, Department of Geriatrics, Bari University Hospital, Italy, between June 1998 and December 1999 were consecutively examined. Our Centre is the largest clinical setting for $\mathrm{AD}$ diagnosis in our region. Probable AD was clinically diagnosed according to the National Institute of Neurological and Communicative Disorders and Stroke/Alzheimer's Disease and Related Disorders Association criteria. ${ }^{13}$ To be eligible for inclusion in this study, patients were required to have a clinical dementia rating scale (range $0-5$ ) score of 0.5 or higher, ${ }^{14} \mathrm{a}$ modified Hachinski ischaemic score (range $0-12$ ) $<3,{ }^{15}$ and a Hamilton depression scale (range 0-67) score less than $17 .{ }^{16}$ After being given a complete description of the study, all subjects or their relatives gave written informed consent.

Blood samples were obtained early in the morning after a 13 hour overnight fast. Serum was removed after centrifugation at $1500 \mathrm{~g}$ for 20 minutes and rapidly frozen and stored at $-80^{\circ} \mathrm{C}$

Abbreviations: AD, Alzheimer's disease; LDL, low density lipoprotein Lp(a), lipoprotein(a); OR, odds ratio; TC, total cholesterol 
Table 1 Demographic features, apolipoprotein E genotypes, total cholesterol (TC), and lipoprotein(a) (Lp(a)) in patients with Alzheimer's disease (AD)

\begin{tabular}{|c|c|c|c|c|}
\hline \multirow[b]{2}{*}{ Variable } & \multicolumn{2}{|l|}{ With AD } & \multicolumn{2}{|l|}{ Without AD } \\
\hline & Men & Women & Men & Women \\
\hline Number & 18 & 43 & 30 & 33 \\
\hline Age (years) & $74.2(7.8)$ & $70.2(10.1)$ & $68.4(10.6)$ & $67(10.8)$ \\
\hline Apolipoprotein E $\epsilon 2$ carrier* & $3(16.7 \%)$ & $2(4.7 \%)$ & $15(50 \%)$ & $15(45.5 \%)$ \\
\hline Apolipoprotein $E \in 3$ homozygous & $10(55.6 \%)$ & $28(65.1 \%)$ & $11(36.7 \%)$ & $14(42.4 \%)$ \\
\hline Apolipoprotein E $\in 4$ carrier $\dagger$ & $5(27.8 \%)$ & $13(30.2 \%)$ & $4(13.3 \%)$ & $4(12.1 \%)$ \\
\hline TC (mmol/l) & $4.89(1.13)$ & 5.01 (0.97) & $6.08(0.98)$ & $5.19(1.17)$ \\
\hline $\mathrm{Lp}(\mathrm{a})(\mathrm{mg} / \mathrm{l})$ & $149.3(181.2)$ & $225.0(255.2)$ & $159.4(201.9)$ & $219.8(257.7)$ \\
\hline 25 th, 50 th, and 75 th percentiles & $4.38,8.83,17.50$ & $1.82,9.61,42.50$ & $1.38,5.85,23.00$ & $1.00,7.00,43.61$ \\
\hline
\end{tabular}

until $\operatorname{Lp}(\mathrm{a})$ evaluation, except for the volume needed for lipid determination analysed the same day. Samples were stored in small volume storage vials that were thawed only once at the time of assay to avoid the differential loss of $\operatorname{Lp}(\mathrm{a})$ antigenicity seen at higher storage temperatures. ${ }^{17}$ Serum Lp(a) concentrations were measured in duplicate by a commercial enzyme linked immunosorbent assay (Immuno $\mathrm{GmbH}$, Heidelberg, Germany). TC was measured by enzymatic colorimetric methods (Boehringer, Mannheim, Germany). DNA was extracted from peripheral blood lymphocytes. Apolipoprotein E genotypes were determined by the polymerase chain reaction restriction fragment length polymorphisms method, reported in detail elsewhere. ${ }^{18}$

Statistical analysis was performed by Pearson's $\chi^{2}$ with a Yates correction to determine whether the observed apolipoprotein E genotype frequencies were in agreement with those determined by the Hardy-Weinberg law. Allele frequencies were determined by allele counting. Differences in age between $\mathrm{AD}$ patients and healthy subjects were evaluated by Student's $t$ test. A model building strategy was developed according to Hosmer and Lemeshow. ${ }^{19}$ A univariate logistic regression analysis was performed to evaluate the relations between $\mathrm{AD}$ and demographic features, apolipoprotein $\mathrm{E}$ genotyping, TC, and $\mathrm{Lp}(\mathrm{a})$ serum concentrations. The variables that were modelled as continuous were examined by quartile analysis to obtain the correct scale in the logit of $\mathrm{AD}$, using the lowest quartile as a the reference group. The evidence of non-linearity suggested that a binary model be calculated. Following Mickey and Greenland, ${ }^{20}$ we used $\mathrm{p}<0.25$ as a screening criterion for selection of candidate variables for the multivariate model. Thus, a multivariate logistic regression model was used to evaluate any significant change in odds ratios (OR) of AD for $\mathrm{Lp}(\mathrm{a})$ serum concentrations, according to a hierarchically well formulated procedure (that is, given any variable in the model, all lower order components of the variable must also be contained in the model). This relation was controlled for covariates (sex, age, apolipoprotein E carriers, and TC concentrations) that could be effect modifiers or confounders. We then assessed confounding, then considered validity and precision. For each analysis, AD was considered to be the dependent variable coded 0 (without $\mathrm{AD}$ ) and 1 (with $\mathrm{AD}$ ). The significance threshold was set at 0.05 . The SAS statistical software package was used for data analysis (SAS Institute, Cary, North Carolina, USA).

\section{RESULTS}

Table 1 shows demographic features, apolipoprotein E genotypes, TC, and $\mathrm{Lp}(\mathrm{a})$ serum concentrations of subjects with and without $\mathrm{AD}$ in relation to sex. No difference in sex (Pearson's $\chi^{2}$ with a Yates correction, 3.56, $p=0.59$ ) was observed, whereas patients with $\mathrm{AD}$ were slightly older than unaffected subjects (mean (SD) age 71.36 (9.56) and 67.67 (10.66), Student's $t$ test 2.03, $\mathrm{p}=0.044$ ). The frequency of the various apolipoprotein $\mathrm{E}$ genotypes in our population was in Hardy-Weinberg equilibrium (patients with AD: Pearson's $\chi^{2}$ with a Yates correction, 4.05, $\mathrm{df}=3, \mathrm{p}=0.26$; healthy subjects: Pearson's $\chi^{2}$ with a Yates correction, $2.17, \mathrm{df}=3$, $\mathrm{p}=0.54$ ).

Table 2 shows the relations between $\mathrm{AD}$ and apolipoprotein $\mathrm{E} \in 4$ carrier, TC, and Lp(a) determined by univariate logistic

Table 2 Univariate logistic models for sex, age, apolipoprotein E genotyping, TC, and Lp(a) in AD

\begin{tabular}{|c|c|c|c|c|c|c|c|c|c|c|c|c|}
\hline Variable & Co & ding & $\begin{array}{l}\text { Number } \\
\text { of } \\
\text { subjects }\end{array}$ & $\begin{array}{l}\text { Number } \\
\text { of events }\end{array}$ & Coefficient & SE & $\begin{array}{l}\text { Log } \\
\text { likelihood }\end{array}$ & $\begin{array}{l}\text { G } \\
\text { statistic* }\end{array}$ & df & $\mathrm{p}$ Value & $\begin{array}{l}\text { Odds } \\
\text { ratio }\end{array}$ & $95 \% \mathrm{Cl}$ \\
\hline Constant & - & - & - & - & - & - & -85.934 & - & - & - & - & - \\
\hline Sex & $\begin{array}{l}0 \\
1\end{array}$ & $\begin{array}{l}\text { Men } \\
\text { Women }\end{array}$ & $\begin{array}{l}48 \\
76\end{array}$ & $\begin{array}{l}18 \\
43\end{array}$ & 0.776 & 0.377 & -83.774 & 4.319 & 1 & 0.04 & 2.17 & 1.04 to 4.55 \\
\hline Age (years) & $\begin{array}{l}1 \\
2 \\
3 \\
4\end{array}$ & $\begin{array}{l}\leqslant 60 \\
61-71 \\
72-76 \\
\geqslant 77\end{array}$ & $\begin{array}{l}33 \\
28 \\
33 \\
30\end{array}$ & $\begin{array}{l}11 \\
13 \\
20 \\
17\end{array}$ & $\begin{array}{l}0 \\
0.550 \\
1.124 \\
0.961\end{array}$ & $\begin{array}{l}- \\
0.529 \\
0.513 \\
0.522\end{array}$ & -82.994 & 5.880 & $\begin{array}{l}- \\
1 \\
1 \\
1\end{array}$ & $\begin{array}{l}- \\
0.30 \\
0.03 \\
0.07\end{array}$ & $\begin{array}{l}1 \\
1.73 \\
3.08 \\
2.62\end{array}$ & $\begin{array}{l}\overline{0} 0.61 \text { to } 4.89 \\
1.13 \text { to } 8.41 \\
0.94 \text { to } 7.27\end{array}$ \\
\hline Apolipoprotein E $\epsilon 4$ carrier $\dagger$ & $\begin{array}{l}0 \\
1\end{array}$ & $\begin{array}{l}\text { No } \\
\text { Yes }\end{array}$ & $\begin{array}{l}98 \\
26\end{array}$ & $\begin{array}{l}43 \\
18\end{array}$ & 1.057 & 0.471 & -83.240 & 5.388 & 1 & 0.03 & 2.88 & 1.14 to 7.25 \\
\hline TC (mmol/) & $\begin{array}{l}1 \\
2 \\
3 \\
4\end{array}$ & $\begin{array}{l}<4.7 \\
4.7-5.3 \\
5.4-6 \\
>6\end{array}$ & $\begin{array}{l}31 \\
30 \\
32 \\
31\end{array}$ & $\begin{array}{l}21 \\
17 \\
15 \\
8\end{array}$ & $\begin{array}{l}0 \\
-0.474 \\
-0.867 \\
-1.798\end{array}$ & $\begin{array}{l}- \\
0.532 \\
0.523 \\
0.562\end{array}$ & -79.840 & 12.189 & $\begin{array}{c}- \\
1 \\
1 \\
1\end{array}$ & $\begin{array}{l}- \\
0.37 \\
0.10 \\
0.01\end{array}$ & $\begin{array}{l}1 \\
0.62 \\
0.42 \\
0.17\end{array}$ & $\begin{array}{l}- \\
0.22 \text { to } 1.77 \\
0.15 \text { to } 1.17 \\
0.06 \text { to } 0.50\end{array}$ \\
\hline Lp (a) (mg/I) & $\begin{array}{l}1 \\
2 \\
3 \\
4\end{array}$ & $\begin{array}{l}<15 \\
15-60 \\
70-355 \\
\geqslant 360\end{array}$ & $\begin{array}{l}31 \\
32 \\
32 \\
29\end{array}$ & $\begin{array}{l}9 \\
16 \\
21 \\
15\end{array}$ & $\begin{array}{l}0 \\
0.894 \\
1.540 \\
0.963\end{array}$ & $\begin{array}{l}- \\
0.531 \\
0.543 \\
0.543\end{array}$ & -81.532 & 8.804 & $\begin{array}{c}- \\
1 \\
1 \\
1\end{array}$ & $\begin{array}{l}- \\
0.08 \\
0.01 \\
0.09\end{array}$ & $\begin{array}{l}1 \\
2.44 \\
4.67 \\
2.62\end{array}$ & $\begin{array}{l}- \\
0.86 \text { to } 6.92 \\
1.61 \text { to } 13.5 \\
0.90 \text { to } 7.59\end{array}$ \\
\hline
\end{tabular}

*Likelihood ratio test statistic; $\dagger \in 3 / \epsilon 4$, and $\epsilon 4 / \epsilon 4$ genotypes. $\mathrm{Cl}$, confidence interval. 
Table 3 Log likelihood (LL), likelihood ratio test statistic ( $G$ statistic), degrees of freedom and $p$ value for possible interactions of interest in $A D$ to be added to the main effects only model

\begin{tabular}{|c|c|c|c|c|c|c|}
\hline Variable & & ding & LL & $\begin{array}{l}G \\
\text { statistic }\end{array}$ & df & $\mathrm{p}$ Value \\
\hline Main effects only* & & - & -70.033 & - & - & - \\
\hline Lp(a) by sex & $\begin{array}{l}0 \\
1\end{array}$ & $\begin{array}{l}\text { Men } \\
\text { Women }\end{array}$ & -53.120 & 2.024 & 3 & 0.54 \\
\hline Lp(a) by age & $\begin{array}{l}0 \\
1\end{array}$ & $\begin{array}{l}<72 \\
\geqslant 72\end{array}$ & -46.952 & 14.360 & 3 & 0.01 \\
\hline $\begin{array}{l}\text { Lp(a) by } \\
\text { apolipoprotein } \epsilon 4 \\
\text { carriert }\end{array}$ & $\begin{array}{l}0 \\
1\end{array}$ & $\begin{array}{l}\text { No } \\
\text { Yes }\end{array}$ & -52.884 & 2.497 & 3 & 0.48 \\
\hline Lp(a) by TC & & - & -51.474 & 5.316 & 3 & 0.15 \\
\hline
\end{tabular}

* Main effects only model from multivariate model containing the following parameters: $\operatorname{Lp}(\mathrm{a})$, sex, age, TC, apolipoprotein $\mathrm{E} \in 4$ carrier; $\uparrow \epsilon 3 / \epsilon 4$ and $\epsilon 4 / \epsilon 4$ genotypes.

regression analysis. Before proceeding to assess interactions in the multivariate model, we needed to examine the variables that were modelled as continuous to obtain the correct scale in the logit. Age and Lp(a) showed no evidence of linearity in the logit of $\mathrm{AD}$. Then we replaced in the multivariate model age and $\operatorname{Lp}(\mathrm{a})$ as continuous variables, each with three design variables using the lowest quartile as the reference group. As table 3 shows, only one interaction was worth pursuing further: $\operatorname{Lp}(\mathrm{a})$ by age. This model seems to provide a significant improvement over the main effects only model for the multivariate model containing Lp(a) sex, age, TC, and apolipoprotein $\mathrm{E} \in 4$ carrier. The inclusion of this interaction term in the model offered a better possibility of describing the effects of high $\operatorname{Lp}(\mathrm{a})$ serum concentrations and age on having AD. For those variables identified as candidates for elimination (sex, apolipoprotein E $\epsilon 4$ carriers, and TC), we then assessed confounding followed by consideration of validity and precision. Table 4 shows that the effect of age on the odds of having $\mathrm{AD}$ increased non-linearly with increasing $\mathrm{Lp}(\mathrm{a})$ serum concentrations, with a plateau between 70 and $355 \mathrm{mg} / \mathrm{l}$ (OR 19.13, 95\% confidence interval 211.5 to 1.73 ). For Lp(a) serum concentrations $\geqslant 360 \mathrm{mg} / \mathrm{l}$, the effect of age $(\geqslant 72$ years) was associated with a reduction in the odds of having $\mathrm{AD}$ (OR $0.15,95 \%$ confidence interval 1.10 to 0.02 ). However, as table 4 shows, the width of the confidence interval indicated that there was a considerable uncertainty in these estimates, in particular for $\operatorname{Lp}(\mathrm{a})$ serum concentrations ranging between 70 and $355 \mathrm{mg} / \mathrm{l}$. Moreover, the only introduction of TC as confounder in the multivariate logistic model containing the interaction term "age by Lp(a)" was associated with a significant change (reduction) in $\mathrm{OR}$ of $\mathrm{AD}$ and narrower confidence intervals than the previous model (OR 11.33 , 95\% confidence interval 101.9 to 1.26 ) (table 4 ) although they were still wide. On the contrary, when controlling for sex alone or apolipoprotein E $\epsilon 4$ carrier alone, no improvement in precision was observed (table 4).

\section{DISCUSSION}

In the present study, $\operatorname{Lp}(\mathrm{a})$ serum concentrations were significantly associated, according to a non-linear relation, with an increased risk for $\mathrm{AD}$, independently of apolipoprotein $\mathrm{E}$ genotypes and dependent on age.

Our findings of lower TC serum concentrations in AD confirm the data of cross sectional and prospective studies in which a weak but significant inverse association with AD was found, independently of apolipoprotein E genotype. ${ }^{621}$ Why the association between $\mathrm{Lp}(\mathrm{a})$ and $\mathrm{AD}$ depends on age is unclear. Plasma concentrations of $\operatorname{Lp}(\mathrm{a})$ are principally determined by the apolipoprotein(a) gene ${ }^{22}$ and recently we found higher $\operatorname{Lp}(\mathrm{a})$ serum concentrations in centenarians than in normolipidaemic younger controls, suggesting that increased Lp(a) may be compatible with the attainment of extreme longevity. ${ }^{23}$ Furthermore, the protective effect of $L p(a)$ in subjects older than 72 years confirmed recent data showing a reduced risk for late onset $\mathrm{AD}$ among $\epsilon 4$ non-carriers older than 80 years. ${ }^{11}$

The results showed that TC serum concentrations improved the precision of the effect modification estimate of age on the relation between $\mathrm{Lp}(\mathrm{a})$ and $\mathrm{AD}$ with respect to the confounding effects of age and $\epsilon 4$. This evidence adjusted the odds of having $\mathrm{AD}$ due to the $\operatorname{Lp}(\mathrm{a})$ on age strata controlling for the effect probably due to LDL cholesterol, a component of TC serum concentrations, because of the molecular similarity between Lp(a) and LDL cholesterol. ${ }^{24}$ These results suggested that the relation between $\mathrm{Lp}(\mathrm{a})$ serum concentrations and $\mathrm{AD}$ should be interpreted on TC strata (as well as age strata), but our small sample didn't allow us to calculate it.

Although female sex did not improve the precision of the effect modification estimate of age on the relation between $\mathrm{Lp}(\mathrm{a})$ and $\mathrm{AD}$, our findings confirmed the increased risk of $\mathrm{AD}$ in women ${ }^{25}$ and the possible role of female sex in increasing Lp(a) concentrations in the elderly through menopause without estrogen replacement. ${ }^{26}$

We found an association between higher $L p(a)$ serum concentrations and $\mathrm{AD}$ independently of apolipoprotein $\mathrm{E}$ genotype, while Mooser $e t$ al $^{11}$ showed a dual apolipoprotein E dependent association between $\operatorname{Lp}(\mathrm{a})$ and AD. These apparently contradictory results can be explained by a possible limitation of the study of Mooser et $\mathbf{l}^{11}$ in their selection of the population sample. In fact, the subjects they studied came from a relatively narrow geographic area of Europe (northern France) and the prevalence of apolipoprotein E genotypes in

Table 4 Change in odds ratio of having AD for Lp(a) serum concentrations controlling for age (coded 1 if $\geqslant 72$ years old), TC, sex (coded 1 if female), and apolipoprotein E $\epsilon 4$ carrier (coded 1 if apolipoprotein E $\epsilon 4$ carrier)

\begin{tabular}{|c|c|c|c|c|c|c|c|c|c|c|c|}
\hline \multirow[b]{2}{*}{ Lp(a) (mg/l) } & \multirow[b]{2}{*}{$\begin{array}{l}\text { Age } \\
\text { (years) }\end{array}$} & \multirow[b]{2}{*}{$\begin{array}{l}\text { With } \\
A D\end{array}$} & \multirow[b]{2}{*}{$\begin{array}{l}\text { Without } \\
A D\end{array}$} & \multicolumn{2}{|c|}{$\begin{array}{l}\text { Lp(a), controlling } \\
\text { for age }\end{array}$} & \multicolumn{2}{|c|}{$\begin{array}{l}\operatorname{Lp}(a) \text {, controlling } \\
\text { for age and TC }\end{array}$} & \multicolumn{2}{|c|}{$\begin{array}{l}\text { Lp }(a) \text {, controlling } \\
\text { for age and sex }\end{array}$} & \multicolumn{2}{|c|}{$\begin{array}{l}\text { Lp (a), controlling for } \\
\text { age and apolipoprotein } E \\
\epsilon 4 \text { carrier }\end{array}$} \\
\hline & & & & $\begin{array}{l}\text { Odds } \\
\text { ratio }\end{array}$ & $95 \% \mathrm{Cl}$ & $\begin{array}{l}\text { Odds } \\
\text { ratio }\end{array}$ & $95 \% \mathrm{Cl}$ & $\begin{array}{l}\text { Odds } \\
\text { ratio }\end{array}$ & $95 \% \mathrm{Cl}$ & $\begin{array}{l}\text { Odds } \\
\text { ratio }\end{array}$ & $95 \% \mathrm{Cl}$ \\
\hline$\leqslant 14.5$ & $\begin{array}{l}\geqslant 72 \\
<72\end{array}$ & $\begin{array}{l}4 \\
5\end{array}$ & $\begin{array}{l}6 \\
16\end{array}$ & 2.13 & 0.40 to 11.28 & 2.10 & 0.36 to 12.26 & 2.03 & 0.41 to 10.07 & 2.41 & 0.43 to 13.46 \\
\hline $15.0-65.0$ & $\begin{array}{l}\geqslant 72 \\
<72\end{array}$ & $\begin{array}{l}9 \\
7\end{array}$ & $\begin{array}{l}6 \\
10\end{array}$ & 2.14 & 0.50 to 9.25 & 1.63 & 0.44 to 6.10 & 2.34 & 0.55 to 9.94 & 2.13 & 0.48 to 9.54 \\
\hline $70.0-355.0$ & $\begin{array}{l}\geqslant 72 \\
<72\end{array}$ & $\begin{array}{l}17 \\
4\end{array}$ & $\begin{array}{l}2 \\
9\end{array}$ & 19.13 & 1.73 to 211.5 & 11.33 & 1.26 to 101.9 & 24.17 & 1.66 to 350.9 & 19.50 & 1.47 to 257.9 \\
\hline$\geqslant 360$ & $\begin{array}{l}\geqslant 72 \\
<72\end{array}$ & $\begin{array}{l}7 \\
8\end{array}$ & $\begin{array}{l}12 \\
2\end{array}$ & 0.15 & 0.02 to 1.10 & 0.15 & 0.01 to 1.15 & 0.14 & 0.02 to 1.27 & 0.13 & 0.02 to 1.14 \\
\hline
\end{tabular}


southern Italy differed from that in northern France. We have just described a geographic trend of apolipoprotein E genotype from northern to southern Europe..$^{18}$ In particular, compared with the allele frequencies in northern and central European countries (populations from Finland and France), a geographic trend for $\epsilon 3$ and $\epsilon 4$ alleles in late onset $\mathrm{AD}$ and middle aged adults was observed. The frequency of $\epsilon 3$ increased from northern to southern Europe, while $\epsilon 4$ decreased significantly. Moreover, the decreased apolipoprotein E $\epsilon 4$ allele frequency in southern Italy gave a different strength of association of this polymorphism with $\mathrm{AD}$ in this geographical area. ${ }^{27}$

The pathophysiological mechanisms by which increased Lp(a) may be associated with AD are unknown. Some studies suggest that the apolipoprotein $\mathrm{E} \epsilon 2$ allele is associated with decreased serum concentrations of $\operatorname{Lp}(\mathrm{a}),{ }^{28}$ but there is no agreement on the influence of apolipoprotein E polymorphism on $\operatorname{Lp}(\mathrm{a})$ concentrations. However, in the present study, high Lp(a) serum concentrations appeared to be associated with increased AD risk, independently of apolipoprotein E genotype. The increase of serum lipoprotein concentrations in $\mathrm{AD}$ may be of interest, as Lp(a), TC, LDL cholesterol, and apolipoprotein $\mathrm{B}$ concentrations are generally related to vascular disease and evidence is growing that vascular factors have a role in the aetiology of AD. In fact, disordered plasma lipoprotein metabolism is central to the pathogenesis of atherosclerosis, a common age related chronic disease. A recent study suggested that atherosclerosis is associated not only with vascular dementia but also with $\mathrm{AD}$, with a significant interaction between apolipoprotein E polymorphism and atherosclerosis in the aetiology of $\mathrm{AD} \cdot{ }^{29}$ Moreover, $\mathrm{Lp}(\mathrm{a})$ is an LDL-like particle, and a recent study found that increased concentrations of serum LDL cholesterol in patients with $\mathrm{AD}$ correlate with brain $\beta$ amyloid $\mathrm{N}-42$ concentrations, suggesting that LDL cholesterol may influence the expression of $\mathrm{AD}$ related pathology. ${ }^{3}$

Furthermore, clinical and epidemiological data have shown that chronic inflammation appears as a precursor of symptomatic $\mathrm{AD}^{30}$ suggesting another possible link between increased serum $\operatorname{Lp}(\mathrm{a})$ and $\mathrm{AD}$. In fact, $\mathrm{Lp}(\mathrm{a})$ concentration has been found to be increased in a number of clinical and subclinical chronic inflammatory disorders. ${ }^{31}$

Finally, recent studies have shown that clinical expression of $\mathrm{AD}$ is facilitated by cerebral ischaemia. In patients with neuropathological brain lesions typical of $\mathrm{AD}$, brain infarcts, and especially lacunar infarcts, more often resulted in clinical dementia. ${ }^{10}$ It was reported that amyloid precursor protein activity and $\beta$ amyloid production increase in the hippocampus of rodents after severe transient ischaemia. ${ }^{32}$ Since increased $L p(a)$ serum concentrations generally enhanced the risk of stroke, ${ }^{8}$ this may have a role in determining clinical AD.

Limitations of our study should be considered. We identified three models controlling age by $\operatorname{Lp}(\mathrm{a})$ interaction for three possible confounders (TC, sex, and apolipoprotein E $\epsilon 4$ carrier) considering each one alone. Because of the small size of the sample groups, we were unable to control $L p(a)$ by age interaction for all lipid and non-lipid potential confounders (ideal estimate). We didn't know whether our reduced models could properly control age by $\operatorname{Lp}(\mathrm{a})$ for confounding. Furthermore, larger clinical studies involving patients with non-AD dementias, as well as longitudinal studies of AD patients, are needed to confirm the relation between $\mathrm{Lp}(\mathrm{a})$ concentrations and AD. Studies in predementia subjects will probably test further the hypothesis that high $\operatorname{Lp}(\mathrm{a})$ serum concentrations may precede the development of cognitive impairment.

\section{ACKNOWLEDGEMENTS}

This study was supported by Italian longitudinal study on aging (ILSA) (Italian National Research Council, CNR-Targeted project on aging, Grants 9400419PF40 and 95973PF40), by co-finanziamento MURST 1998 (ex 40\%), by CARSO Consortium Cancer Research Centre, University of Bari, and AFORIGE (Associazione per la RIcerca e la
FOrmazione in GEriatria). VS, FP, AD, AMC, and CC were supported by a PhD grant in "Carcinogenesis, Ageing, and Immunoregulation" from the European Union. The authors thank Dr Giovanni Castellaneta, Ms Damiana Calamita, and Ms Nicoletta Lobascio for skillful assistance.

\section{Authors' affiliations}

V Solfrizzi, F Panza, A D'Introno, A M Colacicco, C Capurso, A M Basile, A Capurso, Department of Geriatrics, Centre for Aging Brain, Memory Unit, University of Bari, Policlinico, Piazza Giulio Cesare 11, 70124 Bari, Italy

Competing interests: none declared.

Previously presented at the 7th international conference on Alzheimer's disease and related disorders, 9-13 July 2000, Washington DC, USA.

\section{REFERENCES}

1 Saunders AM, Strittmatter WJ, Schmechel D, et al. Association of apolipoprotein E allele e4 with late-onset familial and sporadic Alzheimer's disease. Neurology 1993;43:1467-72.

2 Kalmijn S, Launer $L$, Ott A, et al. Dietary fat intake and the risk of incident dementia in the Rotterdam Study. Ann Neurol 1997;42:776-82.

3 Kuo YM, Emmerling MR, Bisgaier CL, et al. Elevated low-density lipoprotein in Alzheimer's disease correlates with brain Ab 1-42 levels. Biochem Biophys Res Commun 1998;252:71 1-5.

4 Jarvik GP, Wiisman EM, Kukull WA, et al. Interactions of apoliprotein E genotype, total cholesterol level, age, and sex in prediction of Alzheimer's disease: a case-control study. Neurology 1995;45:1092-6.

5 Notkola IL, Sulkava R, Pekkanen J, et al. Serum total cholesterol, apolipoprotein $\mathrm{E} \epsilon 4$ allele, and Alzheimer's disease. Neuroepidemiology 1998;17:14-20.

6 Kuusisto J, Koivisto K, Mykkanen L, et al. Association between features of the insulin resistance syndrome and Alzheimer's disease independently of apolipoprotein E4 phenotype: cross sectional population based study. BM 1997;315: 1045-9.

7 Eaton DL, Fless GM, Kohr WJ, et al. Partial amino acids sequence of apolipoprotein(a) shows that it is homologous to plasminogen. Proc Natl Acad Sci USA 1987;84:3224-8.

8 Zenker G, Koltringer P, Bone G, et al. Lipoprotein(a) as a strong indicator for cerebrovascular disease. Stroke 1986;1 1:942-5.

9 Urakami K, Wada-lsoe K, Wakutani Y, et al. Lipoprotein(a) phenotypes in patients with vascular dementia. Dement Geriatr Cogn Disord 2000;11:135-8.

10 Snowdon DA, Greiner LH, Mortimer JA, et al. Brain infarction and the clinical expression of Alzheimer disease. The Nun study. JAMA 1997;277:813-7.

11 Mooser V, Helbecque N, Miklossy J, et al. Interactions between apolipoprotein $\mathrm{E}$ and apolipoprotein(a) in patients with late-onset Alzheimer disease. Ann Intern Med 2000;132:533-7.

12 Panza F, Solfrizzi V, Torres F, et al. Lipoprotein(a) affects cognitive function in the elderly. The Italian longitudinal study on aging [abstract]. Neurobiol Aging 2000;21 (suppl 1):S34.

13 McKhann G, Drachman D, Folstein M, et al. Clinical diagnosis of Alzheimer's disease: report of the NINCDS-ADRDA Work Group under the auspices of the Department of Health and Human Services Task Force on Alzheimer's Disease. Neurology 1984;34:939-44.

14 Hughes CP, Berg L, Danziger WL, et al. A new clinical scale for the staging of dementia. Br J Psychiatry 1982;140:566-72.

15 Loeb C, Gandolfo C. Diagnostic evaluation of degenerative and vascular dementia. Stroke 1983;14:399-401.

16 Hamilton M. A rating scale for depression. J Neurol Neurosurg Psychiatry 1960;23:56-62.

17 Kronenberg F, Trenkwalder E, Dieplinger H, et al. Lipoprotein(a) in stored plasma samples and the ravages of time. Why epidemiological studies might fail. Arterioscler Thromb Vasc Biol 1996;16:1568-72.

18 Panza F, Solfrizzi $V$, Torres $F$, et al. Decreased frequency of apolipoprotein $E \epsilon 4$ allele from northern to southern Europe in Alzheimer's disease patients and centenarians. Neurosci Lett 1999;277:53-6.

19 Hosmer DW, Lemeshow S. Applied logistic regression. New York: John Wiley \& Sons, 1989:82-134

20 Mickey J, Greenland S. A study of the impact of confounder-selection criteria on effect estimation. Am J Epidemiol 1989;1 29:125-37.

21 Romas SN, Tang MX, Berglund L, et al. APOE genotype, plasma lipids, ipoproteins, and AD in community elderly. Neurology 1999;53:517-21

22 Boerwinkle E, Leffert CC, Lin J, et al. Apolipoprotein(a) gene accounts for greater than $90 \%$ of the variation in plasma lipoprotein(a) concentrations. J Clin Invest 1992;90:52-60.

23 Pepe G, Di Perna V, Resta F, et al. In search of a biological pattern for human longevity: impact of apo A-IV genetic polymorphism on lipoproteins and the hyper-Lp(a) in centenarians. Atherosclerosis 1998; 137:407-17

24 Akanji AO, al-Shayji IAR, Kumar P. Metabolic and anthropometric determinants of serum Lp(a) concentrations and $A p o(a)$ polymorphism in a healthy Arab population. Int J Obes Relat Metab Disord 1999;23:855-62. 
25 Rocca WA, Hofman A, Brayne C, et al. Frequency and distribution of Alzheimer's disease in Europe: a collaborative study of 1980-1990 prevalence findings. Ann Neurol 1991;30:381-90.

26 Jenner JL, Ordovas JM, Lamon-Fava S, et al. Effects of age, sex, and menopausal status on plasma lipoprotein(a) levels. The Framingham offspring study. Circulation 1993;87:1135-41.

27 Panza F, Solfrizzi V, Torres F, et al. Apolipoprotein E in southern Italy: protective effect of $\epsilon 2$ allele in early- and late-onset sporadic Alzheimer's disease. Neurosci Lett 2000;292:79-82.

28 de Kniiff P, Kaptein A, Boomsma D, et al. Apolipoprotein E polymorphism affects plasma levels of lipoprotein(a). Atherosclerosis 1991;90:169-74. 29 Hofman A, Ott A, Breteler MM, et al. Atherosclerosis, apolipoprotein E,
and prevalence of dementia and Alzheimer's disease in the Rotterdam and prevalence of dementia and

30 McGeer PL, McGeer EG. The inflammatory response system of brain: implications for therapy of Alzheimer and neurodegenerative diseases. Brain Res Rev 1995;21:195-218.

31 Baggio G, Donazzan S, Monti D, et al. Lipoprotein(a) and lipoprotein profile in healthy centenarians: a reappraisal of vascular risk factors. FASEB J 1998:12:433-7.

32 Hall ED, Oostveen JA, Dunn E, et al. Increased amyloid protein precursor and apolipoprotein E immunoreactivity in the selectively vulnerable hippocampus transient forebrain ischemia in gerbils. Exp Neurol 1995; 135:17-27

\section{HISTORICAL NOTE}

\section{Hughlings Jackson's "imperception" and anosognosia}

O ne of the earliest to attempts to localise specific functions to anatomical regions of the brain was that of Franz Joseph Gall, ${ }^{1}$ who distinguished six varieties of memory, which he localised in the frontal lobes. Auburtin in 1864 related the faculty of language to the frontal lobes, and Broca ${ }^{2}$ and Dax highlighted the left side of the brain. ${ }^{3}$ The right hemisphere was in some ways regarded as the minor hemisphere, a mirror of the left but without the hierarchically important function of language. Visual and sensory functions were thought to be equally represented in both sides of the brain. Hughlings Jackson first suggested in 1876 the possibility that right hemisphere lesions could produce symptoms and dysfunction not encountered in those with comparably placed lesions of the left hemisphere. Although his paper, addressed to an ophthalmic readership, concentrated on the absence of papilloedema, he undoubtedly described imperception, though not specifically denial of hemiparesis. Jackson ${ }^{4}$ reported a patient with:

"Imperception followed by left hemiplegia, in which the upper arm suffered more than the lower arm, and the leg more than the arm-no optic neuritis [papilloedema]: large glioma of the right posterior lobe."

His patient, Eliza T, aet 59, was under Dr Down's care in March 1875. The history was of two months pain in the head and "neuralgia".

“... She could not find her way from her own house to Victoria Park, a short walk with which she was familiar for 30 years; nor could she find her way home . . . in dressing herself, put her things on wrong side ...."

She developed fluctuating drowsiness, confusion, misidentified time, letters, and faces, and developed left sided hemiparesis.

“...When set to read 12 Snellen ... having got to the end of the line she did not know where to go . . . but no discoverable anaesthesia on the left side ... On trying her for hemiopia, no results were obtained for it was impossible to make her keep her eye fixed on the central point. The only noticeable thing was that she sometimes kept her eye on the central point when asked if she could see an object on her right, but invariably looked at one place on her left. ..."

Dr Gowers performed the autopsy, summarising it as:

"A large gliomatous tumour in the hinder part of the right temporo-sphenoidal lobe: other smaller growths near and in right hippocampus major."

Strictly, anosognosia refers to lack of awareness of the existence of disease. ${ }^{6}$ The interest of this case is Jackson's novel use of the name imperception. ${ }^{7}$ Later workers described lack of awareness, unconcern, or indifference to the disability, even a delusional, ${ }^{6}$ denial of illness or reference of the paralysed limb to someone else, often the examiner. Unilateral sensory changes are common accompaniments. It is often a transient phenomenon. Jackson's patient showed a number of dysphasic errors, which with a possible hemianopia (that was untestable) might explain some of her signs. Jackson reported, "She did not know objects, persons and places". However, he did not object to confusion, loss or defect of memory, or imbecility as contributory factors. But he maintained:

“there was what I would call imperception, a defect as special as aphasia. These admissions [mentioned above] leave the statement that she had imperception untouched . . . I confess, however, that I have little direct evidence as to the localisation of the morbid changes causing imperception."

According to Lord Brain, Hughlings Jackson was the first to recognise both agnosia and apraxia. Pick, later, in 1898 recorded a left hemiplegic who was not aware of his disability. Anton in 1896 (anosognosia for blindness), and F Mueller in 1892 had drawn attention to the same paradox. Jackson called this agnosia: "imperception".8 Indeed, he went on to state that:

"the right posterior lobe is the 'leading' side, the left more automatic in terms of visual ideation . . . for most of our mental operations are carried on in visual ideas."

The imperception of Jackson's patient was probably anosognosia. ${ }^{7}$ Babinski however, provided the name, and fully described the syndrome of anosognosia in left hemiplegia ${ }^{8}$ that enhanced Jackson's idea of specific minor hemisphere syndromes. Babinski remarked:

"I have seen some hemiplegics who, without being ignorant of its existence of their paralysis, seem to attach no importance to it."

In 1918 he wrote:

"Could it be that anosognosia is peculiar to lesions of the right hemisphere?"

\section{JMS Pearce}

304 Beverley Road, Anlaby, HULL HU10 7BG, UK; jmspearce@freenet.co.uk

\section{References}

1 Gall FJ. Craniologie ou dicouvertes nouvelles cancernant le cerveau le crane et les organes (1807). Paris: Necelle and Dictionnaire des Sciences Medicales. Vol 4. 1813:447.

2 Broca PP. Perte de la parole; ramollisement chronique et destruction partielle du lobe antérieur gauche du cerveau. Bull Soc Anthrop Paris $1861 ; 2: 235-8$

3 Pearce JMS. Aphasia and Wernicke's arc. J Neurol Neurosurg Psychiatry 2001;70:699.

4 Jackson JH. Case of large cerebral tumour without optic neuritis and left hemiplegia and imperception. Royal London Ophthalmic Hospital Reports 1876;8:434. Cited in ref 4 .

5 Jackson JH. In: Taylor J, ed. Selected writings of JH Jackson. London: Staples Press, Vol 2. 1958:148-50

6 Zangwill $\mathrm{O}$. Asymmetry of cerebral hemisphere function. In: Garland $\mathrm{H}$ ed. Scientific aspects of neurology. London: Livingstone, 1961:55-7.

7 Brain WR. Speech Disorders. London: Butterworths, 1961. chpt xiii. 143

8 Babinski JFF. Contribution a l'étude des troubles mentaux dans

I'hémiplégie organique cérébrale (anosognosie). Rev Neurol 1914;22:845-8. 